University of Michigan Law School

University of Michigan Law School Scholarship Repository

\title{
An Inquiry Concerning the Functions of Procedure in Legal Education
}

\author{
Edson R. Sunderland \\ University of Michigan Law School
}

Available at: https://repository.law.umich.edu/other/47

Follow this and additional works at: https://repository.law.umich.edu/other

Part of the Civil Procedure Commons, Legal Education Commons, Legal Ethics and Professional Responsibility Commons, and the Legal Profession Commons

\section{Recommended Citation}

Sunderland, Edson R. "An Inquiry Concerning the Functions of Procedure in Legal Education." Am. L. Sch. Rev. 5 (1923): 73-85. (Originally published under the same title in Mich. L. Rev. 21 (1923): 372-92.)

This Speech is brought to you for free and open access by the Faculty Scholarship at University of Michigan Law School Scholarship Repository. It has been accepted for inclusion in Other Publications by an authorized administrator of University of Michigan Law School Scholarship Repository. For more information, please contact mlaw.repository@umich.edu. 


\section{An Inquiry Concerning the Functions of Procedure in Legal Education}

BY EDSON R. SUNDERLAND

University of Michigan Law School

[Address delivered before "Round Table Conference" on Remedies at the annual meeting of the Association of American Law Schools in Chicago, December 29, 1922.]

Pror ROCEDURE has always been the bête noire of the law school teacher. No other subject. has developed such divergent opinions or such endless debates. None recurs with such periodic frequency and in no field of legal pedagogy has discussion seemed so barren of results.

Three different general sessions of the Association of American Law Schools during the last ten years have been devoted largely or wholly to the subject of teaching procedure, and yet no substantial progress seems to have been made toward a standardized scheme of 
treatment. Individual teachers and schools have their individual views and policies, and they go their own ways little affected by the views and policies of others.

But the very insistence with which the problem intrudes upon us suggests not only that there is a widespread and instinctive appreciation of its importance, but also that some solution is possible if we only work at it hard enough. And this brings up the question whether we have ever adequately analyzed the functions whick procedure should perform in legal education. Unless we know what goal we are working toward our progress will be slow enough. But if we can determine what definite purposes are to be realized by teaching procedure, we will be better able to assign to it its true educational values and to place it in proper relation to the rest of the work of the law school. Perhaps we have gone at the problem in the wrong way. Until we know why it should be taught we shall get nowhere in discussing how to teach it. The end to be reached is the best and indeed the only guide to an adequate method.

For this purpose, therefore, I purpose an examination into the reasons why it is desirable that procedure be given a place in a law school curriculum, in the hope that such an inquiry may pave the way for a more satisfactory solution of the problems of pedagogical method and emphasis.

\section{II.}

The most obvious purpose in teaching procedure is to equip the student with the technique which he will be called upon to use in practice. The discussions of the American Bar Association in its section on Legal Education, and of the Association of American Law Schools, have centered about this phase of the subject. Its value has been given different ratings, but has nowhere been wholly denied. The overwhelming opinion is that instruction in procedure is advisable as a preparation for practice within the limits prescribed by two conditions, viz. the development of feasible methods of teaching it and the capacity of a crowded curriculum to hold it against the pressure of other subjects.

As to methods of teaching it is clear that no difficulty occurs with pleading. The case system has absorbed the subject with perfect ease. The principles of trial practice are equally well adapted to the case method. Two casebooks devoted to this subject are in use in American law schools, and after ten years of experience with one of them, and almost as many with the other, it can be stated as a demonstrated fact that trial practice can be taught as easily and successfully with case material as any subject in the law school course.

Appellate practice has not yet been taken up as a law school title, largely, I think, because of the lack of a casebook. But the subject is ideally fitted to the case method of development. Its fundamental problems are quite free from the restrictions of a statutory body of law. The various methods of appellate review, such as writ of error, appeal, certiorari, mandamus, prohibition and certificates, are well defined remedies and proceed upon definite theories which are almost everywhere operative. The question, What is appealable? is one which carries the student into broad questions of appellate policy and develops an accurate sense of the real nature and purpose of appellate review. Only incidentally do the cases turn on local statutes, and even here there is a remarkable similarity in American statutory enactments and a constant recourse to fundamental principles exhibited in their application. The proper parties to an appellate proceeding may be as profitably investigated as parties to actions at law or in equity. The manner and purpose of laying a foundation in the lower court for an appeal, the requisites and the effect of a transfer of the cause, the purpose of a supersedeas and the scope of its operation, the assignment of errors or grounds of appeal and the requisites and preparation of an adequate record on appeal, the scope of the review, and the whole doctrine of harmless or prejudicial error, the effect of affirmance, modifica- 
tion, and reversal, and the character of the proceedings in the lower court after remand-all these matters are full of vital interest to the prospective practitioner and are capable of admirable casebook treatment. They develop fundamental conceptions of judicial administration, and only through a scientific study of appellate theory can one intelligently prepare and effectively carry out proceedings for the review of a cause.

Further development of procedural study, beyond pleading and trial and appellate practice, is doubtless entirely feasible from a teaching standpoint. The nature of judgments and decrees, direct and collateral attack upon them, and their force and effect in bar or estoppel, are extremely important subjects. And it is probable that a study of methods for enforcing judgments and decrees, by execution, attachment, garnishment, and contempt, would prove to be a valuable extension of the field of law school work. All of these additional branches of procedure involve the same pedagogical problems as those which have already been introduced into the school curricula. Material on the study of appellate procedure has been so far worked out that within a year one law school at least will probably be teaching the subject by means of cases. From the side of methodology the theoretical objections have been wholly disproved, and the practical obstacle due to lack of available casebooks is quite likely to disappear in the not distant future.

To what extent the practice court should be resorted to will perhaps con-" tinue to be a mooted question. But it is a minor problem. As between casebooks and cases in the practice court, the individual preferences and characteristics of teachers will have much to do. Probably both should be used. The monotonous nature of continuous casebook study is tending to make students go stale in the latter part of their course, and the practice court furnishes a most welcome and refreshing change, irrespective of its int:insic effectiveness as a method.

The other condition already mentioned, viz. the capacity of a crowded curriculum to admit work in procedure in the face of the immense pressure of substantive courses, is more complex. But it is clear that there is room for all courses which are deemed sufficiently important, so that the question is really one of relative value. Value depends largely on function, so that this phase of the problem fundamentally involves the whole subject of the present paper. The value of procedure as direct equipment for practice cannot be sharply separated from its value for the other purposes which will be presently discussed, but certain suggestions may be derived from available data. It would seem fair to assume that the general value of a subject as direct preparation for practice would be roughly proportional to the volume of actual litigation upon that subject. Such volume may be measured by the amount of space devoted to it in the general digests. This method of computation shows the following interesting. facts :

Three procedural subjects which are given practically no attention in most American law schools, viz. trials, appeal and error, and judgments, demand in the aggregate more than twice as much attention from courts and lawyers as the five typical substantive subjects of bills and notes, contracts, corporations, sales, and trusts, to which American law schools commonly devote about onequarter of the hours required for the law degree. If the same proportion hoids for other substantive subjects, these all but neglected procedural subjects develop about half as much actual difficulty in practice as the whole body of substantive law studied by any given student in his entire law school course. If a certain class of diseases made up half the suffering of the human race, no reputable medical school would attempt to justify a system of medical education which practically ignored them all.

And another significant fact may be drawn from a study of the digests, and that is, that the vast amount of litigation over questions of procedure is not showing any sign of abatement. In the 
discussion of the subject of teaching trial practice which occurred at the meeting of the Association of American Law Schools in Montreal in 1913, one of the speakers suggested that the real reason why that subject had never found an undisputed place in the law school course was that it was an ephemeral subject, which had had its day and was about to pass out of existence. He said:

"Trial practice; in the sense that we have had explained to us to-night, was developed in the United States after 1850. It :-eached its zenith about 1875 , it began its decline about 1900 , and I undertake- to say it will be steadily of less importance in the development of our law in the future."

Now the data from the digests show no such historical development, but rather a steadily rising practical importance. As compared with the five substantive subjects above named (bills and notes, contracts, corporations, sales, and trusts) trial practice showed 28 per cent. as much litigation in the period from the beginning down to 1896,40 per cent. as much from 1897 to 1906 , and 77 per cent. as much from 1907 to 1921. In other wo:ds, the relative amount of litigation on trial practice during the last fourteen years has almost doubled as compared with what it was in the previous ten years. The same data disclose similar results as to the three procedural subjects mentioned (trials, appeal and error, and judgments). In the period prior to 1896 these three procedural subjects furnished 110 per cent. as much litigation as the five substantive subjects already named, from 1897 to 1906 they furnished 143 per cent. as much, and during the last fourteen years, from 1907 to 1921 , they furnished 234 per cent. as much litigation. ${ }^{1}$ Such figures, while perhaps to be taken as approximations merely, can hardly be ignored by

1 Figures are based upon the material appear. ing under the respertive heads in the Century Digest, Decennial Digest, and those averare annual volumes of the American Digest appearing in 1907, 1914, and 1921, except that the material on trials and appeal and error, illog. ically digested under Criminal Law, has benn shifted to those subjects, where it properly belongs. those who are charged with the duty of preparing students to enter into the practice of the law in an unutopian world. An admission by the law schools of their inability to substantially increase their contribution toward making procedural machinery function more efficiently, would be a confession of educational bankruptcy.

\section{III.}

A second purpose to be served by teaching procedure arises from the fact that procedural reform, which is always needed but never so badly as at the present time in the United States, is almost wholly dependent upon a bar educated to want it and to know how it can be obtained. Legislatures cannot deal with the technique of procedure, except through the small group of lawyer members, who usually constitute the judiciary committees. And outside pressure for such legislation, which is an almost indispensable prerequisite for the passage of any act, for general betterment, must come, if at all, from the lawyers practicing in the jurisdiction. Now, lawyers as a class tend not only to be uninterested in new methods for administering jtistice, but they are more than likely to actively oppose them on general principles of policy. Why repeal the technique which they have acquired at so great a cost, and force themselves to learn a new one? The lawyer feels a vested interest in the rules of procedure which he has learned to use. $\mathrm{He}$ is a thorough-going conservative in this field by instinct and training.

This is entirely natural in view of the monopolistic character of judicial administration. If doctors of medicine practiced under a system which necessarily enforced absolute conformity to established technique upon every member of the profession, we should soon see a slowing down of improvement in medical practice. It is competition in methods which gives the stimulus for the development of new ones. No such competition exists in the procedural field of the law. All lawyers must use the same rules. The only opportunity for competi- 
tion is in the use of the old rules, not in the discovery and employment of new rules. Professional ingenuity, therefore, is driven to realize itself through clever refinement in manipulation of the technical system currently in force. This develops a barren formalism, which kills the spirit of progress. A small minority, with a vision transcending the rules around which their professional lives are forced to revolve, feel that legal procedure is out of touch with the changing social order; but they are for the most part only voices crying in the wilderness.

Furthermore, American lawyers are a hard-working body of men, crowded with a thousand duties and responsibilities, with little leisure or nervous energy, even if they felt the inclination, for keeping in touch even with those improvements in judicial administration which have been so systematically developed in British dominions, or which have sporadically sprung up in various parts of the United States. Only a small minority take or read the law magazines. A somewhat larger minority attend Bar Association meetings, state or national, and pick up a few suggestions as to improvements in administrative methods. But when we consider that it is the most enterprising and progressive members of the bar which usually attend such meetings, and then observe how few even of that select group take any active interest in procedural reform, and how many deprecate any substantial departire from the established rules, the wonder is that the system ever improves at all.

It is quite apparent that the professional duties of American lawyers cover the two different functions of making the procedural law and using it in practice. If the law schools are to educate for the profession of the law, they must definitely recognize both these functions; and as between the two their duty to educate the on-coming generations of lawyers in the field of procedural reform is the more pressing, for a lawyer can be at least partially educated in practice at the expense of his clients and the public, after he gets into his professional work, but there is not one chance in a hundred that he will ever develop a real interest or a sound understanding concerning the specific needs and the practical possibilities of procedural reform if left to his own devices. The sorely tried public is quite discouraged over the present methods of judicial administration. They blame the bench and bar. Much of that blame belongs to the law schools. If the schools should seriously take up this great work of laying a foundation for radically improved legal methods, treat-. ing it as a duty and privilege second in importance to no other branch of legal education, they would win both the gratitude and confidence of the public.

The law schools are fully equipped to do this work. Their libraries contain the material necessary for it, and their present curricula can absorb it without substantial readjustment. It should not be conducted as a special seminary course for a few advanced students, but should be brought to the attention of every student who goes through the school. The courses for teaching procedure as currently used in the courts should be employed at the same time for the broader purpose of exhibiting possibilities of improvement. Every procedural doctrine should be subjected to constructive criticism in regular course of instruction. The value of every rule should be tested by its tendency to produce desirable or undesirable results. The causes for dissatisfaction with the operation of rules should be constantly sought, and fundamental misconceptions ruthlessly exposed. No rule should be accepted at its face value merely because it bears the seal of conventional approval. Indeed, procedure should be taught as a mere mechanism designed to reach certain results. It is valuable solely as a means to an end. No rule of procedure should be considered as having any inherent merit whatever. Every one should be studied with reference to two questions: (1) What administrative purpose is it designed to serve? (2) How far does it succeed and how far does it fail in that purpose? Such a study will bring up a third question in each instance, namely: 
What changes in the old rule or what new rule in its place will produce the maximum of advantage while carrying the minimum of inconvenience? In this way procedure will not only be presented to the student as the concrete form under which jurisprudence now realizes itself in action, but the basic nature of the demands made by the law for a workable system of self-expression will be revealed. Fundamental procedural principles will formulate themselves, through such a study, and the resources and possibilities of judicial methods ancl court organization, available for the service of society, will be exhibited. The study of procedure, based on the familiar case material, will therefore be both anatomical and physiological, developing both the structure of the currently employed system and its functional limitations, thus forming a solid basis for building up a rational and practical theory of legal prophylaxis and therapeu. tics.

Lawyers become so accustomed to the forms which they employ that they look upon change as heresy. Principles of law and rules of procedure, being equally operative in the course of the administration of justice, tend to fade into one another and to assume an identical sanctity. Respect for law becomes deference for method, and this produces stagnation in judicial administration. The deadening result can be defeated by the active efforts of the law schools. They must make their students procedural iconoclasts, having no final respect for any rule of practice which is unable to prove its value as a convenient means to a legitimate end.

The strategic strength of the law school position in this field is perfectly well known to all who have given it any thought. And the resultant duty is clear. As Chief Justice Winslow, of Wisconsin, said to the American Bar Association in 1912, in an address on the Relation of I.egal Education to Simplicity in Procedure: "If we are to have simplified procedure which shall accomplish the desired results, we must first have a scientifically educated, as well as a high-minded, bench and bar to administer that procedure. Inasmuch as legal education is now obtained almost exclusively from the law schools, the question how we are to obtain such a bench and bar seems in popular parlance to be 'up to the law schools.' * * * Every law school should give its students a course in scientific simplified procedure, or 'ideal procedure,' if you choose." 2

If the law schools seriously take up this problem they will accomplish farreaching results in removing one of the chief causes of dissatisfaction with the administration of justice by the courts.

$$
\text { IV. }
$$

Beyond the two purposes already considered there is another which is more important than either, although less obvious. It relates to a problem lying at the very foundation of the administration of justice, namely, professional ethics. This has always been a critical point of contact between the laity and the bar. As far hack as our literature runs we find that the people have been keenly dissatisfied with the moral attitude of the legal profession. They are as suspicious of the lawyer's motives as they are critical of his methods, and often feel that technique is only a cloak for iniquity.

Even so kindly a soul as the Quaker, Jonathan Dymond, writing a book upon the Principles of Morality, found it necessary to devote a chapter to the Morality of Legal Practice, and in explanation, said: "If it should be asked why, in a book of general morality, the writer selects for observation the practice of a particular profession, the answer is simply this: That the practice of this particular profession peculiarly needs it. It peculiarly needs to be brought into juxtaposition with sound principles of morality." 3

Now there are lawyers-too many of them-who do not possess the moral character necessary to perform the exacting duties and resist the great tempta-

2 Proc. Am. Bar. Ass'n, 1912, p. 743.

8 Essay II, c. V. 
tions of legal practice. Moral qualifications for admission to the bar are paramount, and the rising tide of opinion that higher educational requirements are necessary is to a very large extent due to the feeling that only the morally sound will have sufficient strength of character to undergo so severe a training. Disbarments prove the presence of the morally unfit, and doubtless such proceedings are far too seldom brought. But I do not believe it can be proved that the standard of morals among men who practice law is lower than among men in other professions or in business or politics. It probably is higher, as it ought to be. Nevertheless I think it is quite evident that the public is convinced that there is something about the professional actions of lawyers which is peculiarly unsatisfactory to the moral sense. So prevalent a belief, arising from a long and intimate experience, may be assumed to rest upon substantial evidence. Is there, then, something about the law itself which draws men who practice it away from the kind of conduct which the public considers moral? I believe there is, and that the training given to lawyers and the habits of mind produced by that training are primarily responsible for the apparent lack of moral quality shown in the administration of the law. The corrective lies in an adequate appreciation of the true function of procedure, as I shall try to show.

Now the law consists of two distinct and almost independent sets of rules or principles; one making up the field of so-called substantive law, the other the field of procedure. The first group is primary, and constitutes an essential part of the structure of society; the second is secondary and derivative, and merely serves to make the first operative. The first group is relatively fixed, and only changes with the slow evolution of social relations; the second is relatively flexible, having no universal quality, but being the mere manifestations of opportunist ingenuity. To radically revise the first would mean a social revolution, but the second could be totally reorganized at a moment's notice, without causing a tremor in the social structure. While the safety and security of civilization may be said to require stability in the first group, safety and security can be realized only by elasticity in the second.

The distinction here made is not absolute but only relative. The principles determining rights and liabilities, while immediately fixed, are ultimately subject to change as social conditions make new principles necessary. Law is undoubtedly a means to an end, and no stage in its development can be called final. Nevertheless this distinction between the substance of law and the form of its operative activity is valid. If we say that real property has a necessarily fixed location, while personal property does not, we speak inaccurately, for no piece of land occupies the same position in space for two consecutive moments. And yet for terrestrial purposes the distinction is sound. So, as a practical matter in dealing with law, we may truly say that the principles of substantive law, as compared with procedure, are fixed and constant, and that the preservation of the status quo is the highest duty of the legal profession; and we may say with equal truth that the rules of procedure, as compared with the substantive law, are variable and in need of perpetual revision, and that the legal profession owes no duty to preserve them, but only to make them useful agencies in the service of society.

The lawyer must therefore develop different attitudes toward the law of rights and duties and the law procedure. As an officer engaged in the administration of the law, he must apply the first with universal impartiality, treating it as the established and true basis of society, and must regard its enforcement as a socially necesiary end in itself. Procedure, on the other hand, he must consider as a mere means whereby such enforcement can be effected in the most efficient and beneficent way. He must recognize the vital difference between the rules by which society adjusts its relations and the rules by which judicial machinery operates. In the procedural field the lawyer is concerned with a mech- 
anism in which society has no interest, except in its tendency to produce results in harmony with social values. In the substantive field he is concerned with the ultimate merits of controversies as determined by the fundamental law, and this involves an exact knowledge of that law and a precise application of its principles to the cases which arise. In this field the lawyer has a definite task, in which society has given him no freedom of action. Generally speaking, it is not for him to pass upon the wisdom or moral quality of the law. That is a legislative matter. In case of doubt as to what the law is on a given subject, he may, of course, urge moral advantages in one rather than another view; but this is a comparatively rare occurrence. In the great bulk of his professional work he is concerned with the purely intellectual task of discovering what the law is, and the equally intellectual task of applying that law accurately, and impartially, coldly, to the facts before him. A case either does or does not fall within a certain rule of law. To determine this question he employs all the skill of a trained logician. $\mathrm{He}$ marshals analogies; he points out distinctions; he analyzes groups of facts and exhibits their logical relations; he refutes alternations by reducing them to absurdities; he builds up series of syllogistic equations. But in all this he passes no ethical judgments. He is concerned not at all with the moral values of the acts involved, but solely with their legal values, and legal values of facts are as far removed from morality as are the mathematical values of spaces and numbers; or the chemical values of mineral elements, or the physical values of ether waves. Like the scientist he is not acting immorally, but non-morallyoutside the moral field.

In the field of procedure, on the contrary, the lawyer is constantly concerned with ethical problems, for that field is the field of professional conduct. Here the question is not what is the law, but what shall I do. Shall I use a capias and arrest the defendant, or a summons and merely give him notice? Shall I annoy my opponent with an attachment? Shall I drag him away from home into a foreign court? Shall I hide my real defense under a general demurrer or a general issue? Shall I ask for a continuance, move for a directed verdict, request certain instructions to the jury, move for a new trial, assign certain errors? All these questions are to be answered by giving moral values to the alternatives of conduct. There are conflicting interests, as in every moral problem. The lawyer must consider his client, but need not wholly forget himself ; he must remember that his opponent has a right to fair treatment, and that society has a large stake in the successful operation of its judicial agencies. Which elements shall, in the particular case before him, have controlling force? On what basis shall he compromise the inconsistent tendencies?

It is quite clear that he cannot justify his conduct by showing that he did nothing positively forbidden under the doctrines of procedure in force, for the rules of procedure have no independent value, but must be deemed good or bad solely in relation to the ends to be reached by them. An automobile has no moral value, but may become an agency for good conduct, as when it carries a physician to a patient's bedside, or for bad conduct, as when it aids a criminal to escape. And the driver, when charged with immoral practice, could hardly defend on the ground that he did nothing contrary to the mechanical rules for the operation of automotive vehicles. So a lawyer in prosecuting a case must answer for his conduct, not by showing that every proceeding which he employed was a well-recognized and legitimate mechanical process for conducting litigation, but he must go further and demonstrate that he employed them for morally justifiable purposes. A distinction must be drawn between the use and the abuse of legal procedure, and this distinction is strictly moral. Every step taken presents the legal problem of utility and fitness, and the ethical problem of rightness or goodness.

There can be no doubt of the moral 
content in procedural acts, for they all entail consequences affecting others. Thus Dewey says: "The moral quality of any impulse or active tendency can be told only by observing the sort of consequences to which it leads in active practice." And again he says: "Consideration of consequences of the act in the way of effect upon the happiness and misery of all concerned, furnishes the only proper way of regulating the formation of right ends." ${ }^{5}$ And still again: "A moral principle, then, is not a command to act or forbear acting in a given way; it is a tool for analyzing a special situation, the right or wrong being determined by the situation in its entirety, and not by the rule as such." ${ }^{\circ}$

Every problem connected with procedure presents a dilemma of conflicting interests with several possibilities of choice. No two procedural situations are identically the same, so that fixed rules for determining conduct cannot be rigidly applied. The principle upon which choice of action must be based is necessarily a moral principle, for legal rules only present the opportunity of choice, but do not solve its problem. If we accept the prevailing theory of utilitarian ethics, which seems peculiarly appropriate in judging the conduct of a public profession, we shall find the true motive of choice to be the greatest aggregate good to the lawyer, his client, the opposing lawyer, and his client, the judge, the jury, the witnesses, and the general public. A conscientious consideration of the rights of all these parties to the litigation will result in a true ethical judgment. Such a judgment will always be a compromise, but this merely demonstrates its moral rather than its legal nature. As Spencer says in his Principles of Ethics:

"Life hourly *** brings individual interests face to face with the interests of other individuals, taken singly or as associated. In many such cases the decisions can be nothing but compromises; and ethical science, here nec-

\& Ethics, by Dewey and Tufts, p. 250 .

B Id. p. 266.

6 Id. p. 334 . essarily empirical, can do no more than aid in making compromises that are the least objectionable. To arrive at the best compromise in any case, implies correct conceptions of the alternative results of this or that course. And, consequently, in so far as the absolute ethics of individual conduct can be made definite, it must help us to decide between conflicting personal requirements and also between the needs for asserting self and the needs for subordinating self." ?

Now, the widespread criticism of the administration of justice relates to the use which is made of the rules of procedure. Complaint is made of delay, uncertainty, and the excessive emphasis upon technical points. Summarized, this only means that the profession is using the rules of procedure, most of which are proper enough in themselves, for improper purposes. In other words, lawyers professionally fail as actors in a moral world.

The reason is not far to seek. Lawyers are concerned with two different fields, one purely legal, one partially ethical, and their training is so largely legal that they allow legal methods and legal standards to exercise a dominant control, to the exclusion of moral elements. The constant aim of the lawyer is to bring the particular case under some established and binding general rule. He seeks resolute results, not approximations or compromises. There is an arbitrary finality about his judgments. One ground for recovery is precisely as good as forty grounds; one defense is exactly equal to another. The defendant is either liable or not liable. There are no intermediate gradations. We have either a valid execution of an instrument or no execution at all. The consideration for a contract is either good or bad-100 per cent. or 0 . The slightest trace of contributory negligence is as utterly destructive of the plaintiff's right as the most wanton recklessness. A life of rectitude weighs nothing against a single false step. There is a ruthlessness in the operation of these rules of the law which refuses to take into account individual

7 Page 284. 
needs or circumstances. Hard cases make bad lcw. Justice is a blindfolded goddess.

Habits of thought acquired by the rigid discipline of the substantive law inevitably follow the lawyer into the field of procedure. Accustomed to form legal judgments as a pure exercise of his logical powers, he naturally pursues the same course in dealing with procedural rules. Unrestricted by moral considerations in the major problems of liability he finds himself equally unconcerned with them in the minor problems of procedure. $\mathrm{He}$ develops a thoroughly consistent and uniform attitude toward all classes of legal questions, which is essentially nonmoral. It ignores ethical principles as irrelevant and immaterial.

Writers on ethics have noted this characteristic of the legal profession. Dewey says that "the 'legally minded' man is likely to be one with whom technical precedents and rules are more important than the good to be achieved and the evils to be avoided," 8 for the legal view of conduct tends to magnify the letter of morality at the expense of its spirit. ${ }^{\circ}$

Knowlson, writing on Originality, asserts that the last person who ought to be allowed to exercise control over governmental agencies is the lawyer, because "the legal mind has too strong a tendency toward guidance by precedent," that is, by formal logic, and is accustomed to a form of mental procedure which is ethically injurious. ${ }^{10}$

The system of legal education which we use is admirably adapted to perpetuate this legalistic attitude. We train for logical accuracy rather than for public service. The spirit of our teaching was well expressed by James Barr Ames when he said that the chief purpose of the Harvard I aw School was to develop "the power of legal reasoning." 11 Most teachers can properly make the same assertion in regard to their own schools. In all the substantive branches of the law we aim to be sure, to give the requi-

8 Dewey and Tufts, Fthics, p. 466.

9 Id. p. 327.

10 Page 213.

11 Proceedings Ass'n Am. Law Schools, 1907, p. 16. site historical and social perspective, and to inpart an adequate amount of technical information, but our great task is to train the mind in legal thinking. Perhaps 80 or 90 per cent. of our effort is directed toward this end. Power in solving legal problems is the final goal of the law school course. If we can graduate men with well trained legal minds, we feel that our work has been well done. ${ }^{12}$

By our very emphasis upon the purely intellectual content of the law we hide the ethical quality of its administration. The logic which solves its problems of liability is assumed to be sufficient to guide the choice of its procedural means. After three years of intensive effort in testing human actions solely by the rigid rules of law, weighing it in a moral vacuum, and judging it by the cold processes of pure reason, how can the student be expected to test his own professional conduct by any other standard?

He has developed a non-moral habit of thought in dealing with juridical data, and that habit follows him in his professional work throughout his career. To use the language of a careful and philosophical observer: "Every lawyer *** has his legal mind formed in its impressionable period by the traditional mode of thinking upon legal and juristic questions. All questions are looked at from the standpoint of this received juristic tradition." 13 The effect of legalism upon the ethical instincts is the same as the effect of asceticism upon the social instincts. They cease to function with normal vigor.

If a concrete demonstration of this inveterate mental habit should be sought,

12 This is often and emphatically stated as a commonplace of legal pedagogy. For example, the following: "The only help for our lawyer lies in his capacity to reason accurately and convincingly from fixed precedents. Hence there slowly arose a recognition of the fact that that law school did most for its students which taught them to think clearly and accurately in terms of settled legal principles, to analyze, test and weigh precedents under the fierce light of reason, and trained them in the art of applying old principles to new states of fact."Vance, "The Ultimate Function of the Tearher of: Law," Pro. Ass'n Am. Law Schools, 1911, p. 33.

13 Pound: "Taught Law," Pro. Ass'n Am. Law Schools, 1912, p. 60. 
the practice in regard to reversals for misconduct of counsel will furnish it. Hundreds of cases may be found in the reports where, by tricks of sharp practice, lawyers have knowingly asked improper questions in order to bring inadmissible evidence to the attention of the jury, have made direct appeal to the jury's prejudices and passions, have browbeaten and insulted witnesses, have 'tampered with members of the panel, have employed false testimony, or have argued beyond the scope of the evidence. Here there is a clear double aspect of the case. The conduct is contrary to legal rules; it is also directly immoral. But in the vast majority of such cases the court limits its action to the former aspect and completely neglects the latter. Legal error looms so large, and moràl delinquency, when put in competition with it, seems so small, to the legalistic mind, that reversal for error is the sole remedy employed. Why merely penalize the innocent client, and let the guilty lawyer go unpunished? There is no lack of power in the court. There is only the lack of moral judgment.

Equally striking is the attitude of many judges in disbarment cases. A lawyer commits deliberate perjury in the court in which he practices. It is proved beyond doubt. A layman, for the same offense, would receive a penitentiary sentence; the lawyer is merely suspended from practice for two or three years. ${ }^{14}$ Another lawyer hires two adventurers to falsely impersonate his clients in effecting a settlement for a large damage claim, himself signs their forged release as a witness and takes the money. For this combined false pretense and forgery he is merely suspended from practice for a couple of years. ${ }^{15}$ The judges in these cases are high-minded men but their legalistic habit of mind, has atrophied their sense of moral values in the field of legal practice.

When Justice John H. Clarke recently commented on the astonishing discussions and distinctions in the field of con-

14 Matter of Andrew J. Sawyer, 1 Mich. Strte Bar Jour. XXVI.

15 Matter of Calvin L. Bancroft, 2 Mich. State Bar Jour. *49. stitutional law which the Supreme Court of the United States was forced to listen to, and observed that ingenuity and refinement were rapidly converting the members of the legal profession in this country into a group of casuists rivaling the Middle Ages schoolmen in subtlety of distinction and futility of argument, ${ }^{18}$ he was only observing the natural effect of our overemphasis of the abstract and logical qualities of the law. The antidote for legal casuistry is a well-developed and ethical conscience in the lawyer's daily professional work.

Legal ethics cannot be effectively taught by lectures or by reading canons of ethics. Most ethical rules which can be formulated are necessarily vague and general, and like all abstractions mean little to the student. What is wanted is a proper habit of mind, not mere information as to conventional standards of legal respectability. The student must accustom himself to an instinctive recourse to moral rather than exclusively legal tests in passing upon procedural problems. He must feel the position of the lawyer as an officer of the court in a thoroughly fundamental and practical sense. He must consider rules of procedure as the forms through which justice is to be realized. The right to practice law is the right to employ procedural processes, and that right is a trust conferred upon the members of the bar for the benefit of society. Every hour in the classroom in procedure should be an hour devoted to a study of the justification of the uses to which procedure may be put.

It is not enough to know what demurrers are designed to do; the deeper question is, what should a lawyer do with demurrers? A case turns upon a special demurrer. Two points are involved: Was the pleading subject to such a demurrer? Was the good to be accomplished by its use sufficient under the circumstances to counterbalance the time, effort, and expense consumed by the parties, the counsel, and the court? A general demurrer is involved. Technique requires no specification of

16 Am. Bar Ass'n Journal, May, 19:2, p. 263. 
grounds; but what can be said of a system which allows a demurrant to lie in wait for his opponent, give him no notice of the point of attack, and overwhelm him with surprise and confusion? A score of requisites for drawing pleadings are taken up one by one. What purpose does each one serve? Is the rule well adapted to reach that purpose? In each case studied is the rule usefully invoked, or has technical zeal or professional callousness made it only a means of annoyance and oppression?

We study the requisites of a writ. Is it a nullity without a seal? The Supreme Court of Georgia, looking at a writ as only a substantial agency for due process of law, can hardly treat the question seriously. ${ }^{17}$ The Supreme Court of Montana, following the United States Supreme Court like a Rip Van Winkle, waking after three centuries of sleep, solemnly declares that a writ without a seal is exactly equivalent to a blank shect of paper, even on a collateral attack, notwithstanding a statute commanding the court to disregard every error or defect in the proceedings not affecting the substantial rights of the parties. ${ }^{18}$ What better material could be found for contrasting the ethical and social standards for administering justice with the legalistic perversion of remedial processes?

The evidence conclusively shows that a defendant charged with murder was lying unconscious on the floor during the whole time that the affray resulting in the killing was going on, but on appeal a verdict against this defendant, who is conceded to be innocent, is sustained solely because a rule of appellate practice requiring the point to be first raised in the trial court was not observed. ${ }^{19}$ Could any one but a lawyer so completely lose the sense of moral values? Could any case more strikingly prove the futility of mere logic as a guide to legal practice?

Every case for a nonsuit or a directed

17 Lowe v. Morris (1853) $13 \mathrm{Ga}, 147$.

18 Chrate v. Spencer (1893) 13 Mont. 127, 32 Pac. 651, 20 L. R. A. 424, 40 Am. St. Rep. 425.

19 State v. Garcia (1914) 19 N. Mex. 414, 143 Pac. 1012. Fortunately this shocking opinion was reversed on a rehearing. verdict involves the question of practical expediency in the use of the institution of the jury. The so-called "scintilla rule" embodies the legal dogma of a jury operating as an end in itself, under rules of pure logic so delicately adjusted that the weight of one hair is a perfectly adequate test of an issue of fact. What so contrary to common sense as the characteristically legal proposition that, since the credibility of witnesses is a question of fact, the jury must be given the oppcrtunity of disbelieving uncontradicted and unimpeached oral testimony? ${ }^{20}$ The legalistic mind makes the jury a fetish; the ethical mind uses it as a practical means for doing substantial justice.

The whole doctrine of new trials and of appeal and error involves a study in ethical compromises. A trial can hardly go on without technical error, which creates a presumption in favor of recurrent new trials. But society cannot afford to maintain a standard of procedural accuracy so high that the expense is cut of proportion to the value of the results. Where shall the line be drawn? How much error will suffice to make a new trial or a reversal on appeal advisable? The cases dealing with motions for new trials are all applications of the rule of social expediency to the infinitely various departures from procedural rules. Questions of appealable orders raise problems of administrative policy, and distinctions between harmless and prejudicial error involve adjustments between the letter and the spirit of remedial law. In all these cases the lawyers and the courts are joint agencies working in the public welfare, and what the courts cannot rightly. grant lawyers cannot rightly urge. Every such case is a concrete problem in public service.

\section{V.}

Such, then, are the three chief functicns of procedure as $i i$ ministers to the cause of legal education. As the beneficiary of an absolute monopoly in the use of procedural processes, the bar is $11 \mathrm{n}$ -

20 Giles v. Giles (1910) 204 Mass. $383,90 \mathrm{~N}$. E. 595 . 
der a definite obligation to acquire adequate knowledge and develop reasonable skill in employing them. The duty to educate in this field lies with the schools. It will not do to say that the technique of practice can be picked up after the student gets into his professional work. The schools must relieve clients from the burden of educating the bar.

Again, the lawyer is the only effective agency for improving the methods of legal administration, since he alone is initiated into its mysteries. No improvement can be expected from an uninformed bar, and information cannot be obtained in the daily conventional routine of a lawyer's work. The schools alone are able to give the knowledge and the outlook, and to create the interest necessary for adequate reform.

Finally, the outstanding failure of the profession to meet the moral demands of the public in their use of the machinery of the law is the result of a lack of perspective rather than of a lack of character. Lawyers overemphasize logic and minimize ethics as a test of professional conduct. They need to acquire an intuitive sense of the ethical values inherent in the choice and use of procedural processes. Only in the schools can this. be done, for there alone are combined the leisure, the detached attitude, the enthusiasm, and the impressionability necessary for creating a permanent basis for a consistent ethical outlook upon professional service.

These functions vitally affect the legal profession. They bear upon that side of the law with which the public is most dissatisfied-its administration. If they have been correctly analyzed in this inquiry, the schools must not only revise their views respecting the importance of procedure, but by their methods of teaching they must make it contribute more effectively to the development of the legal profession as a true public service. 